\title{
Light Vehicle Technology (381)
}

Editor R Brooks

Name $\ldots \ldots \ldots \ldots \ldots$
College $\ldots \ldots \ldots \ldots \ldots$
Employer

\begin{tabular}{|c|c|c|c|}
\hline \multirow{2}{*}{$\begin{array}{r}\text { Session } \\
\text { Day and Time }\end{array}$} & \multicolumn{3}{|c|}{ Class Ref. No. } \\
\hline & Room & Subject & Teacher \\
\hline & & & \\
\hline & & & \\
\hline & & & \\
\hline & & & \\
\hline & & & \\
\hline & & & \\
\hline
\end{tabular}

\begin{tabular}{|c|c|c|c|}
\hline \multicolumn{2}{|l|}{ Session. } & \multicolumn{2}{|c|}{ Class Ref. No. } \\
\hline Day and Time & Room & Subjéct & Teacher \\
\hline & & & \\
\hline & & & \\
\hline & & & \\
\hline & & & \\
\hline & & & \\
\hline & & & \\
\hline
\end{tabular}




\title{
Macmillan Motor Vehicle Series
}

\section{Light Vehicle Technology (381)}

\author{
Editor $\mathbf{R}$ Brooks \\ Senior Lecturer in Motor Vehicle Subjects \\ Bolton College of Education (Technical) \\ Authors J Hirst \\ Lecturer in Motor Vehicle Subjects \\ Burnley Municipal College \\ Examiner in Motor Vehicle Subjects to the \\ Union of Educational Institutions \\ $\mathrm{P} \mathrm{H}$ Seed \\ Lecturer in charge Motor Vehicle Subjects \\ Nelson and Colne College of Further Education \\ J Whipp \\ Lecturer in Motor Vehicle Subjects \\ Moston College of Further Education
}


ISBN 978-0-333-13797-0 ISBN 978-1-349-01596-2 (eBook)

DOI 10.1007/978-1-349-01596-2

(C) 1972

R Brooks J Hirst PH Seed J Whipp

Reprint of the original edition 1972

All rights reserved.

No part of this book may be reproduced or transmitted,

in any form or by any means,

without permission.

First published 1972

THE MACMILLAN PRESS LTD

London and Basingstoke

Associated Companies in

New York Melbourne Toronto Dublin Johannesburg and Madras

SBN 333137973 


\section{PREFACE FOR STUDENTS}

This book follows on directly from the Part 1 book which it is hoped you have used and enjoyed. Again, the aim with this book is to make the task of students easier and more rewarding by cutting down on the possibly wasteful and repetitious work that you would have to do within the framework of the old-fashioned system of note taking and sketch making.

It is suggested that where you write or sketch in the book, that you do so in pencil; simply so that if you do make any mistakes, they can be easily and neatly erased. Just because there are blank lines and spaces, it does not mean that every such space must be filled completely. They are provided so that you can add information to the extent you require.
The book has been very carefully structured so that much of the information you put into it can be about vehicles that are of special interest to yourself. This should make it an especially worthwhile and valuable record that can be shown to parents and employers as a positive indication of progress.

The units of measurement used throughout the book are predominantly the SI units, although where practicable the comparable Imperial units are also included. This, it is hoped, will help in the present period of transition, especially as certain items of motor vehicle work will have to be carried out using Imperial units for some time to come. 


\section{PREFACE FOR TEACHERS}

This book is one of a pair that have been designed specifically to meet the requirements of the 381 (previously 551) Motor Vehicle Craft Studies Course in a stimulating and interesting manner; and as a direct follow-on to the Part 1 book in this Series.

All the information has been carefully structured so as to appeal to the student and encourage him in his studies. He is saved much of the chore of note taking and laborious sketching which in itself can be a considerable obstacle for the less able student. The need for several writing and text books is avoided

The form of presentation enables teachers to be relieved of many of the less attractive and time-wasting chores of lesson preparation and delivery, yet by the same token enables more time to be devoted to 'real' teaching.
Particular care has been taken to allow-within the confines of the syllabusfor the flexibility of approach so vital to the individual teacher; and also to allow students a certain degree of freedom of choice. However, the layout is such that marking and checking on progress remains simple. Numerous sections could, if thought desirable, be set in place of traditional old-style homework.

In accordance with modern practice the book uses primarily the SI units of measurement, although where practicable, comparable Imperial units are also included. This it is hoped, will help in the present period of transition. However, the text has been carefully structured to allow the majority of the work to be done in the unitary system of the teacher's choice. 


\section{ACKNOWLEDGEMENTS}

British Leyland Motor Corporation Limited

Audi N.S.U. Auto Union AG.

Rolls-Royce Motors Limited

A-C Delco Division of General Motors Limited

Ford Motor Company Limited

Chrysler U.K. Limited

Champion Sparking Plug Company Limited

Dunlop Limited

Pirelli Limited

Avon Rubber Company Limited

Goodyear Tyre and Rubber Company (Great Britain) Limited

Motor Trader
British Standards Institution

Firestone Tyre and Rubber Company Limited Joseph Lucas Limited

Vauxhall Motors Limited

Smiths Industries Limited

Automotive Products Group

Girling Limited

Halls Gaskets Limited

Holset Engineering Company Limited

CAV Limited

Crypton-Triangle Limited 